\title{
EVIDENCE FOR A NEW CLASS OF UTERINE STIMULANTS IN RAT SEMEN AND MALE ACCESSORY GLAND SECRETIONS
}

\author{
W. P. VENTURA AND M. FREUND \\ Laboratory of Reproductive Pharmacology, Departments of Pharmacology and of Obstetrics \\ and Gynecology, New York Medical College, Flower and Fifth Avenue Hospitals, \\ New York, N.Y., U.S.A.
}

(Received 5th September 1972)

Sperm transport through the female reproductive tract in most mammals occurs within a few minutes of coitus and is rapid and passive, i.e. it is not due to sperm motility but rather to some agent or agents, such as oxytocin and semen, which modify uterine motility (Evans, 1933; Yamanaka \& Soderwall, 1960; First, Short, Peters \& Stratman, 1968). The uterine contracting and relaxing properties of human and ram semen have been reported to be due to prostaglandins (von Euler, 1936; Eliasson, 1959; Bygdeman, 1964). Von Euler (1936) isolated and named prostaglandin, a weak organic unsaturated carboxylic acid containing hydroxyl groups, from human and ram seminal plasma and noted that it had a marked stimulatory effect on uterine smooth muscle. Subsequently, many compounds of the prostaglandin family have been isolated (Eliasson, 1959; Bygdeman, 1964). The prostaglandin content of rat semen is unknown, but von Euler (1936), Eliasson (1959), Horton \& Thompson (1964) and DeCuminsky \& Mercuri (1971) reported that homogenized rat seminal vesicles contained $0.5 \mu \mathrm{g}$ prostaglandins/g of tissue. We have shown that rat semen and lateral and posterior prostate gland fluids stimulate the motility of the rat female reproductive tract in vitro (Ventura, 1969), but the fluids from the seminal vesicles, Cowper's glands, and coagulating glands did not have a stimulatory effect on the uterus.

The purposes of this investigation were to measure the prostaglandin content of rat semen and male accessory gland fluids by use of a very sensitive bioassay, before and after fractionation and purification by thin-layer chromatography; and to determine what is the contribution, if any, of prostaglandins to the spasmogenic activity of rat semen.

Semen from CFE-strain rats (Carworth Farms) was collected by electroejaculation (Ventura, 1969), pooled, frozen, and stored at $-20^{\circ} \mathrm{C}$. The uterine stimulatory action of an aliquot of raw rat semen was tested on the isolated rat uterus preparation (Ramwell \& Shaw, 1966) and compared with a known dose of $\mathrm{PGE}_{1}$. The results showed that each $\mathrm{ml}$ of rat semen was equivalent, in terms of spasmogenic activity, to $200 \mathrm{ng} \mathrm{PGE}_{1}$. Rat semen was fractionated by a procedure which separates lipids from other tissue constituents which might have spasmogenic activity and which also permits 
extraction of prostaglandins (Text-fig. 1). The efficiency of the fractionation procedure was tested by adding $73 \mathrm{ng}\left[5,6-{ }^{3} \mathrm{H}\right] \mathrm{PGE}_{1}$ to the sample. The aqueous and organic extracts were analysed for content of $\left[5,6-{ }^{3} \mathrm{H}\right] \mathrm{PGE}_{1}$ and the results showed that $91 \%$ of the label was in the ethyl acetate extract, $6 \%$ was in the aqueous extract, and 3\% was in the petroleum ether extract. An aliquot of the ethyl acetate extract was chromatographed on thin-layer chromatographic plates (silica gel $\mathrm{H}$ ) and compared with chromatograms of $\mathrm{PGA}_{1}$, $\mathrm{PGE}_{1}$ and $\mathrm{PGF}_{1}$. The prostaglandin standards were developed by spraying with alcoholic ammonium molybdate $(10 \%)$. The $R_{\mathrm{F}}$ values for $\mathrm{PGA}_{1}, \mathrm{PGE}_{1}$ and $\mathrm{PGF}_{1}$ were $0.69,0.52$ and 0.36 , respectively.

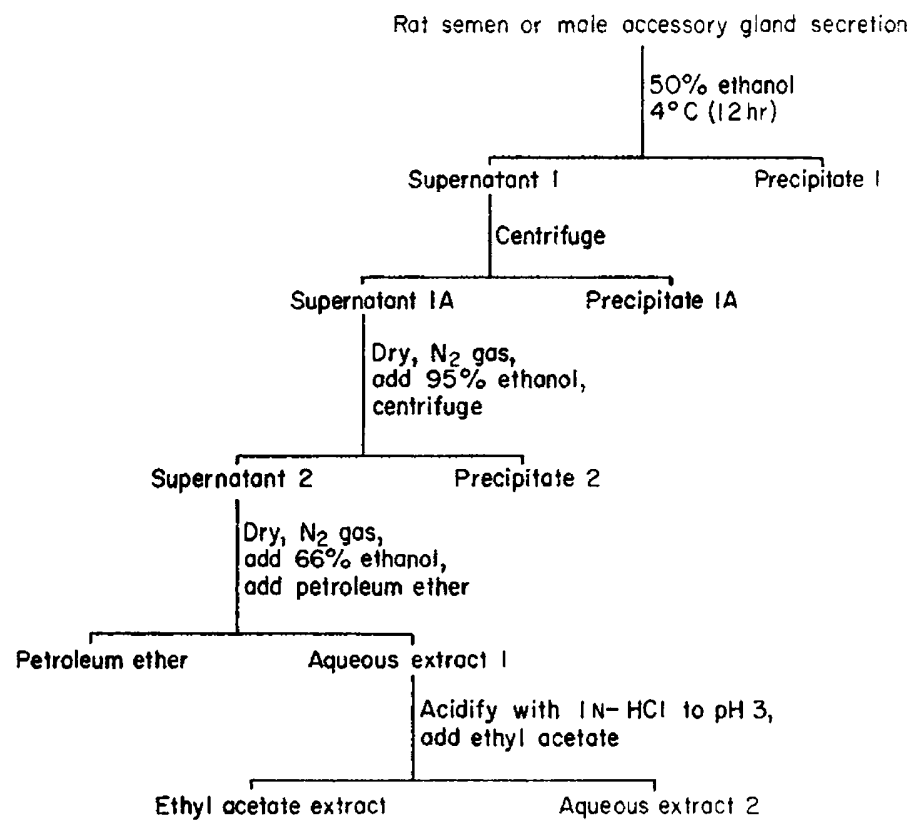

TeXT-FIG. 1. Flow chart : prostaglandin fractionation procedure.

Each area was scraped from the plate and subjected to bioassay (Ramwell \& Shaw, 1966), which was carried out as follows. The whole uterine horn obtained from an ovariectomized rat was mounted in a $0.5-\mathrm{ml}$ bath containing de Jalon's solution (de Jalon, 1947), aerated and maintained at room temperature $\left(23\right.$ to $\left.25^{\circ} \mathrm{C}\right)$. The dose response to a purified prostaglandin $\left(\mathrm{PGE}_{1}\right)$ was determined and a known quantity of the fluid to be assayed was added. Using this procedure, the concentration of prostaglandin in rat semen and in the fluid sample from each male accessory gland was estimated by comparing the response to the added fluid with the response to $\mathrm{PGE}_{1}$. The results showed that each $\mathrm{ml}$ of rat semen contained $1 \mathrm{ng} \mathrm{PGE}_{1}$ and $0.5 \mathrm{ng} \mathrm{PGF}_{1}$. These results extend the findings of von Euler (1936), Eliasson (1959), Horton \& Thompson (1964) and DeGuminsky \& Mercuri (1971), and demonstrate that the stimulatory action of rat semen on the uterus is not due to the presence of prostaglandins. Analysis of the fluid from each of the male rat accessory glands 
following extraction and scraping from thin-layer chromatographic plates showed that (1) seminal vesicle gland fluid contained $1 \mathrm{ng} \mathrm{PGE}_{1}$ and $1 \mathrm{ng}$ $\mathrm{PGF}_{1} / \mathrm{ml}$; (2) coagulating gland (anterior prostate) fluid contained $13 \mathrm{ng}$ $\mathrm{PGE}_{1}$ and $10 \mathrm{ng} \mathrm{PGF}_{1} / \mathrm{ml}$; (3) lateral prostate gland fluid contained $13 \mathrm{ng}$ $\mathrm{PGE}_{1}$ and $13 \mathrm{ng} \mathrm{PGF}_{1} / \mathrm{ml}$; and (4) posterior prostate gland fluid contained $10 \mathrm{ng} \mathrm{PGE}_{1}$ and $3 \mathrm{ng} \mathrm{PGF}_{1} / \mathrm{ml}$.

All of the uterine stimulatory activity was found in the aqueous fraction from which the prostaglandin had been previously extracted with ethyl acetate at $\mathrm{pH}$ 3. This finding led to a further investigation of the nature of the spasmogenic substance in rat semen and prostatic gland fluid which stimulated uterine motility.

The spasmogens of the fluids of the rat prostate gland complex (anterior, lateral and posterior lobes) and rat semen were extracted by the procedures of Folch, Lees \& Sloane-Stanley (1957) and Svennerholm (1963). The spasmogens isolated by these techniques were soluble in water, chloroform:methanol (2:1

Table 1. A comparison of the molar ratios of rat semen spasmogen, rat prostatic fluid spasmogen and bovine brain ganglioside

\begin{tabular}{l|c|c|c|c}
\hline & $\begin{array}{c}\text { Hexose } \\
\text { sialic acid }\end{array}$ & $\begin{array}{c}\text { Hexose } \\
\text { hexosamine }\end{array}$ & $\begin{array}{c}\text { Sialic acid } \\
\text { hexosamine }\end{array}$ & $\begin{array}{c}\text { Sialic acid) } \\
\text { sphingosine }\end{array}$ \\
\hline Bovine brain (S) & 1.1 & $2 \cdot 4$ & 2.2 & 1.4 \\
Rat semen (S) & 1.2 & 2.5 & 1.8 & 1.9 \\
Rat semen (F) & 1.0 & 1.1 & 1.0 & 1.6 \\
Rat prostatic fluid (S) & 1.1 & 2.3 & 2.0 & 1.9 \\
Rat prostatic fluid (F) & 1.1 & 1.2 & 1.0 & 1.7 \\
\hline
\end{tabular}

(S)-Values obtained using the Svennerholm extraction method.

(F)-Values obtained using the Folch extraction method.

and 1:2) and were non-dialysable through cellophane. The results of the chemical analyses of the spasmogen components are listed in Table 1. In addition to the semen and prostatic fluid component analyses, Table 1 also contains data on the components of bovine brain gangliosides. Bovine brain gangliosides were purchased from Nutritional Biochemicals (Gleveland, Ohio) and were re-extracted by the Svennerholm (1963) method.

It is interesting to note that the main difference in the values obtained for the spasmogens isolated from rat semen and prostatic fluids by the Folch and Svennerholm procedures are the hexosamine and nitrogen values. It appears that the Folch method (cold solvents) is a mild extraction procedure and does not remove the nitrogen-containing moieties attached to the spasmogen, while the Svennerholm method (hot solvents) denatures or splits the nitrogencontaining moieties attached to the spasmogen.

The thin-layer chromatographic migration properties of rat semen and rat prostatic fluid spasmogens and bovine brain gangliosides were determined on silica gel G plates using solvent systems A, propanol:water (7:3), and B, chloroform:methanol:water $(60: 35: 8)$. The spasmogens were detected by iodine vapours and charring the plates with sulphuric acid $(25 \%)$. The results 
(Table 2) indicate that rat semen spasmogens, rat prostatic fluid spasmogens and bovine brain gangliosides have similar $R_{\mathrm{F}}$ values.

It is important to emphasize that sialic acid was found in concentrations between 85 and $125 \mathrm{mg} / 100 \mathrm{ml}$ rat semen. This concentration range was similar to the finding of Warren (1959), who reported concentrations between 64 and $219 \mathrm{mg} / 100 \mathrm{ml}$ human semen.

In addition to having similar chemical and thin-layer chromatographic properties, rat semen spasmogens, rat prostatic fluid spasmogens and bovine brain gangliosides are equally potent as uterine stimulants when tested on spontaneously active rat uterine horns mounted in the in-vitro system used in this laboratory (Freund, Wiederman \& Saphier, 1963).

Table 2. A comparison of the $R_{\mathrm{F}}$ values of rat semen spasmogen, rat prostatic fluid spasmogen and bovine brain ganglioside extracted by the Svennerholm method

\begin{tabular}{|c|c|c|c|c|c|c|}
\hline $\begin{array}{l}\text { Time } \\
\text { and } \\
\text { temp. }\end{array}$ & $\begin{array}{l}\text { Solvent } \\
\text { system }\end{array}$ & Tissue & Spot 1 & $\begin{array}{l}R_{\mathrm{F}} \text { values } \\
\text { Spot } 2\end{array}$ & Spot 3 & Spot 4 \\
\hline $\begin{array}{l}3 \frac{1}{2} \mathrm{hr} \\
24^{\circ} \mathrm{C}\end{array}$ & $\begin{array}{l}\text { Propanol : } \\
\text { water }(7: 3)\end{array}$ & $\begin{array}{l}\text { Bovine brain } \\
\text { Rat semen } \\
\text { Rat prostatic fluid }\end{array}$ & $\begin{array}{l}0.25 \\
0.24 \\
0.25\end{array}$ & $\begin{array}{l}0.29 \\
0.27 \\
0.30\end{array}$ & $\begin{array}{l}0.37 \\
0.35 \\
0.38\end{array}$ & $\begin{array}{l}0.42 \\
0.40 \\
0.44\end{array}$ \\
\hline $\begin{array}{l}2 \mathrm{hr} \\
25^{\circ} \mathrm{C}\end{array}$ & $\begin{array}{l}\text { Chloroform : } \\
\text { methanol : } \\
\text { water }(60: 35: 8)\end{array}$ & $\begin{array}{l}\text { Bovine brain } \\
\text { Rat semen } \\
\text { Rat prostatic fluid }\end{array}$ & $\begin{array}{l}0 \cdot 10 \\
0 \cdot 09 \\
0 \cdot 11\end{array}$ & $\begin{array}{l}0.13 \\
0 \cdot 11 \\
0.13\end{array}$ & $\begin{array}{l}0 \cdot 18 \\
0 \cdot 18 \\
0 \cdot 16\end{array}$ & $\begin{array}{l}0.22 \\
0.21 \\
0.21\end{array}$ \\
\hline
\end{tabular}

These results indicate that the major spasmogen in rat semen and prostatic fluid is not prostaglandin but appears to belong to a new class of uterine stimulants which have the chemical and physical properties of gangliosides.

The authors wish to thank Dr R. N. Peterson and Dr J. Shaw for their assistance in this investigation. This work was supported by Grants HD-00488-11 and HD-03466-10 from the National Institute of Child Health and Human Development, and by a Grant from the Lalor Foundation.

\section{REFERENCES}

Bygdeman, M. (1964) The effect of different prostaglandins on human myometrium in vitro. Acta physiol. scand. 63, Suppl. 242, 1.

DeGuminsky, B. S. \& MERCURI, O. (1971) Identification of prostaglandins $E_{1}$ in rat seminal vesicle gland. Lipids, 6, 278.

DE JALON, G. P. (1947) El uso de las sales de magnesio en las ensayos de las extractos de lobulo posterior de hipofisis. Farmacoter. act. 4, 177.

Eliasson, R. (1959) Studies on prostaglandin. Acta physiol. scand. 46, Suppl. 158, 1.

Evans, E. J. (1933) Transport of sperm in the dog. Am. J. Physiol. 105, 287.

First, N. L., Short, R. F., Peters, J. B. \& Stratman, F. W. (1968) Transport of boar sperm in estrual and luteal sows. F. Anim. Sci. 27, 1032.

Folch, J., Lees, M. \& Sloane-Stanley, G. H. (1957) A simple method for the isolation and purification of total lipids from animal tissues. F. biol. Chem. 226, 497.

Freund, M., Wiederman, J. \& SAPHIER, A. (1963) A method for the simultaneous recording, in vitro, of the motility of the vagina, of the body of the uterus, and of both uterine horns in the guinea pig. Fert. Steril. 14, 416. 
Horton, E. W. \& Thompson, C. J. (1964) Thin layer chromatography and bioassay of prostaglandins in extracts of semen and tissues of the male reproductive tract. Br. F. Pharmac. Chemother. 22, 183.

Ramwell, P. W. \& SHaW, J. E. (1966) Spontaneous and evoked release of prostaglandins from the cerebral cortex of anesthetized cats. Am. F. Physiol. 211, 125.

Svennerholm, L. (1963) Chromatographic separation of human brain gangliosides. F. Neurochem. 10, 613.

VENTURA, W. P. (1969) An in-vitro investigation of the effects of rat semen and male accessory gland secretions on the motility of the rat female tract. Ph.D. thesis, New York Medical College, N.Y.

voN EULER, U. S. (1936) On the specific vaso-dilating and plain muscle stimulatory substances from accessory genital glands in man and certain animals. (prostaglandin and vesiglandin). $\mathcal{F}$. Physiol., Lond., 88, 213.

WARREN, L. (1959) Sialic acid in human semen and in the male genital tract. F. clin. Invest, 38, 755.

Yamanaka, H. S. \& Soderwall, A. L. (1960) Transport of spermatozoa through the female genital tract of hamsters. Fert. Steril. 11, 470. 